\title{
JUPIIS: Jurnal Pendidikan Ilmu-ilmuSosial
}

Available online http://iurnal.unimed.ac.id/2012/index.php/iupiis

\section{Pembelajaran Pendidikan Kewarganegaraan Menggunakan Metode Inquiry untuk Meningkatkan Hasil Belajar Siswa}

\section{Citizenship Education Learning Using Inquiry Methods to Improve Student Learning Outcomes Hotma Siregar ${ }^{1)}$ \& Suryani2)}

1) Jurusan Pendidikan Pancasila dan Kewarganegaraan, Fakultas Keguruan Ilmu Pendidikan Universitas Muhammadiyah Sumatera utara, Indonesia

2) Madrasah Aliyah Negeri 1 Medan, Indonesia

Diterima: 19 November 2019; Disetujui: 09 Maret 2020; Dipublish:30 April 2020

\begin{abstract}
Abstrak
Penelitian ini bertujuan untuk mengetahui apakah dengan diterapkannya metode pembelajaran inquiry dapat meningkatkan hasil belajar siswa di kelas XII MIPA I Madrasah Aliyah Negeri 1 Medan Tahun Pelajaran 2019/2020. Penelitian ini merupakan penelitian tindakan kelas yang terdiri dari 2 siklus. Setiap siklus terdiri dari 4 tahap yaitu perencanaan, pelaksanaan, observasi, dan refleksi. Tehknik pengumpulan data yang digunakan adalah observasi dan test. Test terdiri dari pretest, postest siklus I, dan postest siklus II dan observasi meliputi aktivitas guru dan siswa. Hasil penelitian menunjukkan adanya peningkatan hasil belajar siswa. Proses peningkatan tersebut, terlihat mulai dari dilakukannya test awal dengan perincian dari 49 orang siswa diperoleh 15 orang siswa (30,61\%) yang mendapat nilai tuntas, sedangkan 34 orang siswa belum tuntas. Pada postest siklus I naik menjadi 30 orang siswa $(61,22 \%)$ yang mendapat nilai tuntas, sedangkan 19 orang siswa (38,78\%) belum tuntas. Pada postest Siklus II dari 49 orang siswa diperoleh 47 orang siswa $(95,91 \%)$ mendapat nilai tuntas, sedangkan 2 orang siswa $(4,09 \%)$ mendapat nilai belum tuntas. Dengan demikian dapat disimpulkan bahwa dengan penerapan metode pembelajaran inquiry dapat meningkatkan hasil belajar siswa pada mata pelajaran Pendidikan Kewarganegaraan jurusan MIPA Madrasah Aliyah Negeri 1 Medan Tahun Pelajaran 2019 /2020.
\end{abstract}

Kata Kunci: Metode Inquiry, Hasil Belajar, Pendidikan Kewarganegaraan

\section{Abstract}

This study aims to determine whether the application of inquiry learning method can improve student learning outcomes in class XII MIPA I Madrasah Aliyah Negeri 1 Medan 2019/2020 Academic Year. This research is a classroom action research study consisting of 2 cycles. Each cycle consists of 4 stages, namely planning, implementation, observation, and reflection. Data collection techniques used were observation and test. The test consists of pretest, posttest Cycle I, and posttest Cycle II and observation includes the activities of teachers and students. The results showed an increase in student learning outcomes. The improvement process can be seen starting from the initial test with the breakdown of 49 students obtained by 15 students (30.61\%) who received complete scores, while 34 students received incomplete grades. In the first cycle post-test, it increased to 30 students (61.22\%) who received complete marks, while 19 students (38.78\%) received incomplete grades. In the Post Cycle II out of 49 students, 47 students (95.91\%) received complete marks, while 2 students (4.09\%) received incomplete grades. Thus it can be concluded that the application of inquiry learning method can improve student learning outcomes in the subject of Civics Education majoring in Madrasah Aliyah Negeri 1 Medan in 2019/2020 Academic Year.

Keywords: Inqury Method, Learning Outcomes

How to Cite: Siregar, H \& Suryani (2020). Pembelajaran Pendidikan Kewarganegaraan Menggunakan Metode Inquiry untuk Meningkatkan Hasil Belajar Siswa. JUPIIS: Jurnal Pendidikan Ilmu-ilmuSosial, 12(1): 212-219.

*Corresponding author:

E-mail: Pertama @gmail.com
ISSN 2549-1660 (Print) ISSN 2550-1305 (Online) 


\section{PENDAHULUAN}

Pembentukan watak dan peradaban bangsa yang bermartabat dalam rangka mencerdaskan kehidupan bangsa, dan menjadikan manusia sebagai warganegara yang demokratis dan bertanggung jawab secara filosofis, sosio-politis dan psikopedagogis, merupakan (mission sacre) dari pendidikan kewarganegaraan (Winataputra dalam Ihsan 2017).

Sebagaimana yang diatur dalam Pasal 37 ayat (1) Undang-Undang No.20 Tahun 2003 tentang Sistem Pendidikan Nasional bahwa "Pendidikan Kewarganegaraan dimaksudkan untuk membentuk peserta didik menjadi manusia yang memiliki rasa kebangsaan dan cinta tanah air". (Silvia, Fitri dan Dadang Sundawa 2015). Jika dikaji lebih jauh maka pemerintah melalui undangundang tersebut memiliki tujuan menyiapkan generasi muda agar memiliki sikap kritis sebagai warganegara.

Pembelajaran inquiry adalah salah satu model pembelajaran yang menstimulus siswa untuk berpikir kritis, sehingga mampu menganalisis persoalan yang telah dirumuskan terlebih dahulu. Rasa ingin tahu siswa akan terpenuhi karena model meneliti seperti ini dapat memperkuat dan mendorong secara alami untuk mengeksploitasi sehingga kegiatan dapat dilakukan dengan semangat yang besar dan penuh kesungguhan. Menurut Sanjaya dalam (Nurhani dkk 2016) Pengetahuan itu akan bermakna manakala dicari dan ditemukan sendiri oleh siswa, sehingga konsep yang telah dipelajari oleh akan tertanam kuat dalam benak siswa. Dengan demikian tujuan pembelajaran dalam upaya membantu mengatasi kesulitan siswa dalam memahami materi (Dharma \&, Siregar. 2015; Khairat, 2016; Nasution, 2016; Tanjung, 2017; Tambunan, 2017).

Siswa dalam mempelajari sesuatu yang baru akan lebih efektif apabila siswa bertanya dan berpartisipasi secara langsung mengemukakan pendapat di depan kelas, agar terlatih berani dan memiliki kualitas yang unggul dalam potensi yang dimilikinya.

Mata pelajaran PKn adalah mata pelajaran ilmu sosial yang mempelajari aspek-aspek yang berhubungan dengan manusia dan lingkungan sosialnya. Oleh karena itu, mata pelajaran PKn lebih banyak membahas teori-teori (Setiawan, 2014; Dharma \& Siregar, 2014)

$$
\text { Menurut Budimansyah }
$$

"Pengetahuan kewarganegaraan (civic knowledge) berkaitan dengan kandungan atau apa yang seharusnya diketahui oleh warga Negara." Setiap warga negara sudah seharusnya mengetahui apa yang menjadi hak dan kewajibannya. Pengetahuan tentang hak dan kewajiban sebagai warga negara tidak datang dengan sendirinya, melainkan diperoleh melalui proses pendidikan.

Hasil observasi awal, peneliti melihat bahwa mata pelajaran PKn kurang menarik bagi siswa-siswa di jurusan MIPA, karena terlalu banyak membahas teori-teori dan sifatnya menghapal. Disisi lain, jurusan MIPA terbiasa untuk memecahkan masalah dengan menggunakan rumus.

Saat ini mayoritas peserta didik masih menganggap bahwasanya PPKn merupakan pelajaran yang hanya berisi hafalan tentang pemerintahan, undang-undangan atau aturan hukum yang lain, sehingga yang tertanam di benak peserta didik adalah bahwa dengan kemampuan menghafal yang tinggi maka 
diyakini dapat menguasai suatu konsep mampu mengarahkannya untuk menyadari tertentu untuk memperoleh hasil belajar apayang telah didapatkannya selama ini. yang maksimal (Istikhomah, Nur dan Suripno 2019; Suharyanto, 2017).

Inquiry menempatkan siswa sebagai

Untuk subjek pembelajaran yang aktif. Kendati pun penguasaan siswa terhadap satu mata namun guru tetap memegang peranan pelajaran, maka diperluakan ujian. Hasil penting sebagai pembuat desain pengalaman belajar digunakan sebagai ukuran untuk belajar. Guru berkewajiban membimbing mengetahui seberapa jauh siswa menguasai untuk melakukan kegiatan. Guru bahan yang telah diajarkan., memberikan penjelasan, membimbing

Penelitian ini bertujuan untuk diskusi, memberikan komentar dan saran mengetahui apakah dengan menggunakan kepada siswa. Guru berkewajiban metode pembelajaran inquiry dapat menyediakan fasilitas, media dan materi meningkatkan hasil belajar siswa jurusan pelajaran. MIPA di Madrasah Aliyah Negeri 1 Medan.

Menurut Trianto (dalam Suid dkk Menurut Madjid (2013), bahwa strategi 2016), "Hasil belajar merupakan perubahan inquiry merupakan cara memberikan pada diri seseorang sebagai hasil dari proses pengertian dengan menstimulasi anak didik belajar yang dapat diindikasikan dalam untuk memperhatikan, menelaah dan bentuk, seperti berubah pengetahuan, berpikir tentang suatu masalah untuk pemahaman, sikap dan tingakah laku, selanjutnya menganalisis masalah tersebut kecakapan, keterampilan dan kemampuan". sebagai upaya untuk memecahkan masalah.

Sementara itu, menurut Winkel dalam

Dalam konteks mengajar, inquiry pada dasarnya adalah cara menyadari apa yang telah dialami, metode inquiry menuntut peserta didik berpikir.Pembelajaran inquiry dapat dianggap sebagai suatu latihan dalam memperoleh pengetahuan. Siswa diberi pernyataan untuk mengembangkan kesimpulan berdasarkan pertimbangan (Triswanti, 2017) keberhasilan penerapan suatu metode didasarkan kepada perubahan yang mengakibatkan manusia berubah dalam sikap dan tingkah lakunya.

\section{METODE PENELITIAN}

Penelitian ini merupakan penelitian bukti-bukti yang telah dimilikinya. yaitu penelitian yang dengan sengaja Selanjutnya siswa ditugaskan untuk dilakukan untuk merencanakan, menjawab dengan menggunakan berbagai melaksanakan kemudian mengamati dampak sumber belajar.

dari pelaksanaan tindakan tersebut pada

Menurut Mulyasa (2005), metode subjek penelitian. Menurut Kunandar (dalam inquiry adalah metode yang menempatkan Mulia S. dan Suwarno 2016), PTK merupakan siswa sebagai subyek belajar yang aktif dan penelitian tindakan yang dilakukan oleh guru 
sekaligus sebagai peneliti di kelasnya atau menyiapkan lembar kerja, mensetting bersama-sama dengan orang lain ruangan kelas dan membagi kelompok. (kolaborasi) dengan jalan merancang, 2. Pelaksanaan (Action) melaksanakan, dan merefleksikan tindakan Pada tahap ini, guru menjelaskan pokok secara kolaboratif dan partisipatif yang bahasan, menyertakan media yang berkaitan bertujuan untuk memperbaiki atau dengan pokok bahasan, mempersiapkan satu meningkatkan kualitas proses pembelajaran masalah yang harus dijawab berdasarkan di kelasnya melalui suatu tindakan tertentu kelompok, jawaban satu kelompok akan dalam suatu siklus.

Menurut Arikunto, dkk (2010) diberi komentar oleh kelompok lain dengan cara menempelkan kertas post it, membuat :"Langkah-langkah Penelitian Tindakan Kelas kesimpulan. secara umum ada 4 tahapan yang dilakukan, 3. Pengamatan (Observasi)

yaitu 1) Perencanaan (Planning), 2) Pelaksanaan (Action), 3) Pengamatan (Observation), 4) Refleksi (Reflection)". Adapun prosedur penelitian ini dapat di lihat pada bagan di bawah ini :
Gambar 1

Siklus PenelitianTindakan Kelas

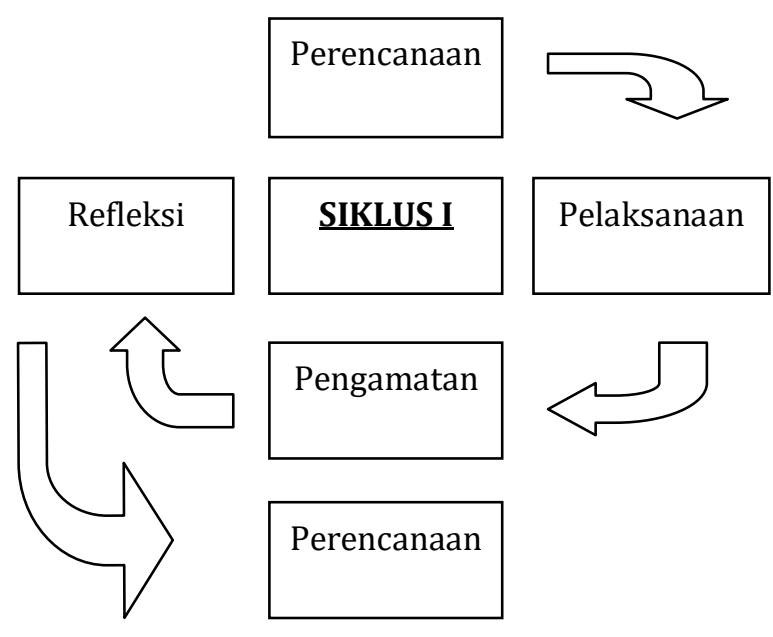

Tahap pengamatan ini dilakukan oleh guru untuk melihat seberapa jauh efek tindakan yang telah mencapai sasaran. Pengamatan akan dilakukan dengan lembar observasi

\section{Refleksi (reflektion)}

Pada tahapan ini dilakukan evaluasi terhadap tindakan yang telah dilakukan. Kemudian melakukan pembahasan terhadap lembar observasi, untuk selanjutnya mengambil kesimpulan yang akan digunakan sebagai acuan ke siklus berikutnya.

\section{HASIL DAN PEMBAHASAN}

Adapun hasil perolehan nilai dan persentase siswa saat pretes dan postes adalah sebagai berikut :

Tabel 1.Hasil Pretes

\begin{tabular}{|l|l|l|}
\hline No & Keterangan & Hasil Pretes \\
\hline $\mathbf{1}$ & Tuntas & $30,61 \%$ \\
2 & Tidak tuntas & $69,39 \%$ \\
\hline
\end{tabular}

\section{Perencanaan Penelitian (Planning)}

Pada tahap ini yaitu: mempersiapkan RPP untuk menentukan materi pembelajaran, mengembangkan skenario pembelajaran, menyiapkan sumber belajar,
Dari tabel di atas, dapat dilihat bahwa hasil pretes yang telah dilakukan menunjukkan bahwa hanya 15 (limabelas) orang siswa yang sudah tuntas. Sementara itu 34 orang siswa lainnya dinyatakan belum tuntas.

Tabel 1.Hasil Postes 


\begin{tabular}{|c|c|c|c|}
\hline \multirow[t]{2}{*}{ No } & \multirow{2}{*}{ Keterangan } & \multicolumn{2}{|c|}{ Hasil Pretes } \\
\hline & & Siklus 1 & Siklus II \\
\hline 1 & Tuntas & $71,43 \%$ & $100 \%$ \\
\hline 2 & Tidak tuntas & 28,57 & o\% \\
\hline
\end{tabular}

Dari tabel hasil postes pada siklus I dapat dilihat bahwa siswa yang tuntas sebanyak 35 orang yaitu sebesar 71,43 persen dan yang tidak tuntas hanya 14 orang atau sebanyak 28,57 persen. Mengukur ketuntasan siswa dalam belajar menurut Usman (2001) digunakan rumus :DS $=\frac{\text { Skor yang diperoleh siswa }}{\text { skor maksimal }} \times 100 \%$

Misalnya untuk menghitung ketuntasan siswa yang bernama Romadon adalah sebagai berikut :

$$
\begin{aligned}
D S= & \frac{\text { Skoryangdiperolehsiswa }}{\text { skormaksimal }} \times 100 \% \\
& \text { DayaSerap }=\frac{90}{100} \times 100 \% \\
= & 90
\end{aligned}
$$

Jadi daya serap Romadon adalah 90 pada saat postest siklus I.

Untuk menghitung ketuntasan secara klasikal menurut Mulyasa (2004) digunakan rumus : $D=\frac{X}{N} X 100 \%$

Dimana:

D: Ketuntasan Klasikal

$\mathrm{X}$ :Jumlah siswa yang mendapat nilai 70 (tuntas) $\mathrm{N}$ : Jumlah siswa yang mengikuti tes

Dari rumus diatas maka ketuntasan klasikal siklus I adalah sebagai berikut:

$$
\begin{aligned}
D & =\frac{35}{49} X 100 \% \\
& =71,43 \%
\end{aligned}
$$

Dengan demikian, dapat disimpulkan bahwa sampai pada siklus I tindakan yang dilakukan belum tuntas, karena siswa yang tuntas belajar hanya 35 orang yaitu sebesar 71,43 persen, sedangkan ketuntasan kelas tercapai jika dari jumlah keseluruhan siswa mencapai lebih besar atau sama dengann 75 persen.

Oleh karena pada siklus I belum memenuhi ketuntasan klasikal, maka tindakan dilanjutkan pada siklus II. Berdasarkan refleksi dan analisis yang dilakukan di akhir siklus I, maka dilakukan kembali perlakuan yang sama yaitu menerapkan metode inquiry dalam proses pembelajaran Pendidikan kewarganegaraan. Hasil pada siklus II menunjukkan terjadinya perubahan yang terlihat dari hasil postes, dimana siswa yang tuntas sebanyak 49 orang yaitu 100 persen. Artinya tidak ada siswa yang tidak tuntas.

Penelitian dilaksanakan di dalam kelas dengan menerapkan metode inquiry saat kegiatan pembelajaran berlangsung. Pada awal kegiatan diberikan pretes untuk mengetahui sejauh mana tingkat pemahaman siswa terhadap materi tentang pengingkaran terhadap hak asasi manusia. Apabila hasil belajar siswa ternyata dibawah kriteria ketuntasan minimal yaitu nilai 77 maka siswa dianggap belum tuntas dalam pembelajaran. Apabila 75 persen dari jumlah siswa belum mencapai nilai 77 maka ketuntasan secara klasikal belum terpenuhi sehingga penelitian dilanjutkan ke siklus berikutnya.

Pada siklus II, Setelah diadakan refleksi dan hasilnya tidak memenuhi kriteria ketuntasan minimal secara klasikal yaitu 75\%, maka peneliti kembali membuat 
rencana pembelajaran dengan materi Di akhir Siklus II ini dilakukan postes untuk Pengingkaran Hak Asasi Manusia mengetahui kemampuan akhir siswa dan menggunakan metode inquiry dengan peningkatan kemampuan setelah diterapkan langkah -langkah sebagai berikut:

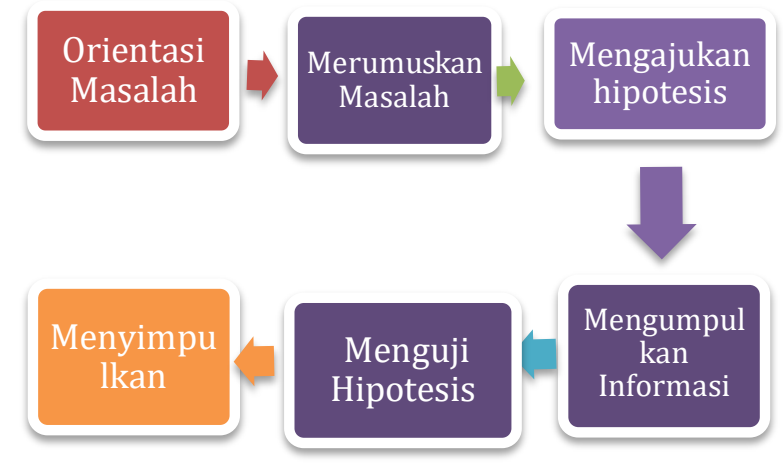
metode inquiry. Pada siklus II ini diperoleh peningkatan hasil dari nilai rata-rata yang diperoleh dari siklus I yaitu $71,43 \%$ menjadi $100 \%$. Ketuntasan hasil belajar pada siklus II meningkat drastis dari siklus I.

\section{SIMPULAN}

Daripaparan hasil dan pembahasan di atas, maka dapat disimpulkan bahwa proses pembelajaran dengan menerapkan metode inquiry dapat meningkatkan hasil belajar

Langkah pertama guru menjelaskan materi Pengingkaran Hak Asasi Manusia. Berdasarkan penjelasan ini, siswa dapat merumuskan masalah untuk selanjutnya membuat hipotesis. Untuk dapat menjawab hipotesis, maka siswa mengumpulkan informasi melalui bahan bacaan ataupun internet. Langkah selanjutnya dilakukan pengujian terhadap hipotesis. Langkah terakhir setiap kelompok harus membuat kesimpulan. Kesimpulan harus dipresentasikan di depan kelas dengan menggunakan kertas karton.

Setelah selesai presentasi, maka guru menunjuk secara acak, kelompok yang akan memberi tanggapan terhadap materi yang telah dipaparkan oleh kelompok tersebut. Tanggapan tersebut akan ditanggapi lagi oleh kelompok lain. Disini terlihat masing-masing kelompok berusaha menyampaikan tanggapan terbaiknya. Adu argument terjadi diantara masing-masing kelompok dan hal itu membuat proses pembelajaran menjadi lebih menarik.

Pada pertemuan berikutnya dilakukan hal yang sama, sampai materi terselesaikan. Negeri 1 Medan.

Inkuiri bukan hanya metode atau pendekatan pembelajaran, melainkan juga sebuah filosofi belajar. Siswa dilatih untuk bertanya kemudian menentukan strategi atau cara menjawab, menganalisis dan akirnya menemukan jawabaan dari pertanyaanya (Bai F,Arnoldus dan Dyah Rspati S.S 2017).

Peningkatan hasil belajar tersebut dapat terlihat pada tabulasi angka yang didapat dari hasil pretes dan postes. Sebelum penerapan metode pembelajaran inquiri dilaksanakan, maka terlebih dahulu dilakukan pretes dan hasilnya menunjukkan bahwa hanya 15 (limabelas) orang siswa yang sudah tuntas. Sementara itu 34 orang siswa lainnya dinyatakan belum tuntas.

Selanjutnya diberilah perlakuan dengan menerapkan metode inquiry pada mata pelajaran PKn dengan materi pengingkaran hak asasi manusia dalam dua siklus. Pada siklus I penelitian belum tuntas, karena siswa yang tuntas belajar hanya sejumlah 35 orang. 
Berdasarkan refleksi dan analisis yang dilakukan di akhir siklus I, maka proses pembelajaran dilanjutkan kesiklus II dengan tetap menggunakan metode yang sama. Pada tahap akhir dilakukan postes dengan hasil siswa yang tuntas sebanyak 49 orang, artinya tidak ada siswa yang tidak tuntas Model pembelajaran inquiry. Membuat siswa menjadi lebih aktif dan kreatif dalam mengikuti kegiatan belajar mengajar yang sedang berlangsung, sehingga mata pelajaran PKn juga diminati oleh siswa jurusan MIPA.

\section{UCAPAN TERIMA KASIH}

Peneliti mengucapkan terima kasih kepada pihak-pihak yang telah membantu terlaksananya peelitian ini yaitu: Dekan Fakultas Keguruan Dan Ilmu Pendidikan Universitas Muhammadiyah Sumatera Utara, yang telah menugaskan peneliti mengikuti program PDS, Kepala Sekolah Madrasah Aliyah Negeri 1 Medan yang telah mengizinkan peneliti melakukan penelitian di sekolah tersebut.

\section{DAFTAR PUSTAKA}

Suid, A.B. dkk. (2016). Pengaruh Metode Pembelajaran Inkuiri Pada Subtema Gerak Dan Gaya Terhadap Hasil Belajar Siswa Kelas Iv Sdn 16 Banda Aceh. Jurnal Pesona Dasar Uniersitas Syiah Kuala. Volume 3 Nomor 4. Hal.75

Arikunto, S. (2010). Prosedur Penelitian Suatu Pendekatan Praktik. Jakarta. Rineka Cipta.

Bai F. Arnoldus dan Dyah Respati S.S. (2017). Keefektifan Implementasi Pendekatan Saintifik Dengan Metode Inkuiri Dan Problem-Based Learning ditinjau Dari Minat Siswa. Jurnal Pendidikan IPS UNY.Volume 4 Nomor 1.Hal.94.
Budimansyah, D. (2010). Penguatan Pendidikan Kewarganegaran untuk Membangun Karakter Bangsa. Bandung.WidyaAksaraPress

Dharma, S dan Siregar. R, (2015). Membangun Pengalaman Belajar Kewarganegaraan melalui Model Pembelajaran Project citizen pada Siswa, Jurnal Pendidikan Ilmu-Ilmu Sosial, 7 (1) (2015): 100-106.

Dharma, S. dan Siregar, R. (2014). Internalisasi Karakter melalui Model Project Citizen pada Pembelajaran Pendidikan Pancasila dan Kewarganegaraan, Jurnal Pendidikan Ilmu-Ilmu Sosial 6 (2) (2014): 132-137

Ihsan, (2017), Kecenderungan Global Dalam Proses Pembelajaran Pendidikan Pancasila Dan Kewarganegaraan Di Sekolah,Junal Pancasila dan Kewarganegaraan, UMP, Volume 2 Nomor 2,Hal.49

Istikhomah, N. dan Suripno. (2019). Upaya Meningkatkan Kemampuan Berpikir Kritis Siswa Pada Mata Pelajaran PPKn di SMP SeKecamatan Sentolo. Jurnal Pendidikan Kewarganegaraan Dan Hukum UNY, Volume 8 Nomor 9, Hal.820

Khairat, (2016), Pembelajaran Contextual Teaching and Learning (CTL) dalam Meningkatkan Hasil Belajar Pendidikan Kewarganegaraan pada Materi Demokrasi, Jurnal Pendidikan Ilmu-Ilmu Sosial, 8 (1) (2016): 80-87.

Madjid. (2013). Model-Model Pembelajaran. Jakarta. Raja Grafindo

Mulia, S.D. dan Suwarno. (2016). Ptk (Penelitian Tindakan Kelas) Dengan Pembelajaran Berbasis Kearifan Lokal Dan Penulisan Artikel Ilmiah Di Sd Negeri Kalisube, Banyumas. Jurnal Ilmiah Kependidikan UMP.Volume IX Nomor 2.Hal.3

Mulyasa. (2005).Model-Model Pembelajaran. Jakarta. Raja Grafindo Persada.

Nasution, A.R., (2016), Urgensi Pendidikan Kewarganegaraan sebagai Pendidikan Karakter Bangsa Indonesia melalui Demokrasi, HAM dan Masyarakat Madani, Jurnal Pendidikan IlmuIlmu Sosial, 8 (2) (2016): 201-212.

Nurhani. (2016). Penerapan Metode Inquiri Dalam Meningkatkan Hasil Belajar Siswa Pada mata Pelajaran IPA Di Kelas IV SDN 3 Siwalempu. Jurnal Kreatif Universitas Tadulako.Volume 4 Nomor 2. Hal.103

Setiawan, D. (2014). Pendidikan Kewarganegaraan Berbasis Karakter melalui Penerapan Pendekatan Pembelajaran Aktif, Kreatif, Efektif 
Hotma Siregar \& Suryani, Pembelajaran Pendidikan Kewarganegaraan Menggunakan Metode Inquiry

dan Menyenangkan, Jurnal Pendidikan IlmuIlmu Sosial, 6 (2): 61-72.

Sofyan S, Fitri dan Sundawa, S. .(2015). Hubungan Mata Kuliah Pendidikan Kewarganegaraan Dengan Peningkatan Wawasan Kebangsaan Dan Semangat Nasionalisme Mahasiswa. Jurnal Pendidikan Ilmu Sosial UPI Volume 24 Nomor 2 Hal.184

Tambunan, B., (2017). Upaya Meningkatkan Hasi Belajar Pendidikan Kewarganegaraan melalui Penerapan Model Pembelajaran Kooperatif Point-Counter-Point, Jurnal Pendidikan IlmuIlmu Sosial, 9 (2): 239-245

Tanjung, J., (2017). Penerapan Model Pembelajaran Kooperatif Make A Match dalam Meningkatkan Hasil Belajar Pendidikan Kewarganegaraan, Jurnal Pendidikan Ilmu-Ilmu Sosial, 9 (2): 224230
Triswanti, E. (2017). Pengaruh Metode Pembelajaaran Inkuiri Terhadap Hasl Belajar Praktik Kewirausahaan Ditinjau Dari Tingkat Kognitif Siswa. Jurnal Penelitian Dan Penilaian Pendidikan UHAMKA. Olume 2 Nomor 2. Hal.179

Usman. (2011). Teori Hasil Belajar. Jakarta. Bumi Aksara.

Suharyanto, A. (2017). Pemahaman Siswa Tentang Konsep Demokrasi Dalam Pendidikan Kewarganegaraan, dalam Prosiding Seminar Nasional Tahunan Fakultas Ilmu Sosial Universitas Negeri Medan Tahun 2017 Vol. 1 No. 1 2017, Hal. 530-534 